\title{
A Scale to Measure the Perspective of Farmers' towards Agriculture
}

\author{
Bhargab Baruah $^{1 *}$ and Hemanga Kr. Kalita ${ }^{2}$ \\ ${ }^{1}$ Department of Extension Education, College of Agriculture, Assam Agricultural University, \\ Jorhat, Assam, India \\ ${ }^{2}$ Department of Extension Education, Sarat Chandra Singha College of Agriculture (AAU), \\ Rangamati, Dhubri, Assam, India \\ *Corresponding author
}

\section{A B S T R A C T}

\section{Keywords \\ Perspective, Agriculture, Livelihood, Rural areas, Likert's scale \\ Article Info \\ Accepted: \\ 08 August 2018 \\ Available Online: \\ 10 September 2018}

\begin{abstract}
Farmers make the decision to quit farming altogether only after comparing the utility they derive from farming as compared to taking up a full-time non-farm employment. Thus, an attitude scale was developed to measure the perspective of practicing farmers towards agriculture as a livelihood in rural areas. Likert's scale of summated rating technique was followed for constructing the scale. A total of 44 statements were selected after obtaining the relevancy scores and administered to 30 farmers whose principal source of income is agriculture from non-sampled areas in Assam, India. The scale developed finally consisted of 30 statements including 15 positive and 15 negative statements. The reliability and validity of the scale indicated its precision and consistency of the results.
\end{abstract}

\section{Introduction}

At the time of independence in India, around 70 per cent of population depended on agriculture for their livelihood and agriculture accounted for more than 50 per cent of GDP. Seventy years later, more than fifty per cent of population depends on agriculture for their livelihood with agriculture accounting for only one-seventh of the GDP. During these seventy years agriculture has attained self-sufficiency in food grain production, have seen modernization in parts, and many schemes have been forwarded by the government in the seven decades for the welfare of farming community and agriculture as a whole. In spite of all this the existing condition of farmers' are pathetic in the country. A large proportion of agricultural workers, especially the youth are on their way out of agriculture in India. Farmers make the decision to quit farming altogether only after comparing the utility they derive from farming as compared to taking up a full-time non-farm employment.

Jones (2013) acknowledged that humans' process time in a subjective manner, whereby they psychologically reconstruct events and outcomes in order to better understand their experiences and to help them to form future expectations. Lewin (1951) defined time perspective as the totality of the individual's views of his psychological future and psychological past at a given time. Farmers' 
perspective towards agriculture may be defined as the point of view, understanding and beliefs of farmers about agriculture for overall development of self and community.

As there was no scale available to measure the farmers' perspective towards agriculture the present study was contemplated to develop and standardize a scale for measuring farmers' perspective. This is a part of the larger Ph.D. research study on"A Study on Farmers' Perspective towards Agriculture in the last five decades in the state of Assam" that is in progress.

\section{Materials and Methods}

Perspective in the present study was operationalised as the degree of positive and negative feeling of the practicing farmers towards agriculture as a livelihood in relation to their well-being, social status, selffulfillment, and risks and opportunities involved in agriculture.

The method of summated rating as suggested by Likert (1932) was followed in the development of the scale on farmers' perspective. A Likert scale consists of a set of items or statements to which the subject is asked to respond with degrees of agreement or disagreement carrying different scores.

\section{Collection and editing of statements}

A total of 80 statements representing the perspective of farmers' towards agriculture were collected from available literature and in consultation with expertsin the field of extension education.

The statements were carefully edited on the basis of criteria suggested by Thurstone, Likert and Edward (Edward, 1957). Finally, a list of 65 statements was retained and 15 statements were eliminated.

\section{Relevancy test}

There was a possibility that all the statements collected may not be equally relevant in measuring the perspective of farmers towards agriculture. As such, these statements were subjected to scrutiny by a panel of experts to determine the relevancy and screening for inclusion in the final scale.

The panel comprised of experts in the field of the concerned subject of the universities, research and extension institutes. The statements were sent to 120 experts with request to critically evaluate each statement and to determine their relevancy on a 3 point continuum viz., most relevant, relevant and not relevant with the score of 3,2 and 1 , respectively and reverse for the negative statements. Out of 120 experts only 40 responded in a time span of 60 days. The relevancy score of each item was ascertained by adding the scores on the rating scale for all the 40 judges' responses. Then the Mean Relevancy Percentage, Mean Relevancy Weightage and Mean relevancy Score were calculated for all the statements in the following manner:

\section{Relevancy percentage (RP)}

It is the number of respondents who rated the statements as "most relevant" and "relevant", which is converted into percentage.

$$
R P=\frac{F S}{\text { no.of respondents }} \times 100
$$

$\mathrm{FS}=$ frequency score of most relevant and relevant

\section{Relevancy weightage (RW)}

It is the ratio of actual score obtained to the maximum possible scores obtainable for each statement. 
$R W=\frac{A S}{M P S}$

$\mathrm{AS}=$ Actual scores obtained for the statement

MPS=Maximum possible scores obtainable for the statement

\section{Mean relevance score (MRS)}

It is the ratio of actual score obtained by each respondent to the number of judges responded for the variable.

$$
\text { MRS }=\frac{\text { Actual score obtained for item }}{\text { No. of judges responded }}
$$

Using these three criteria the statements were screened for their relevancy. Accordingly, statements having relevancy percentage $>70$, relevancy weightage $>0.70$ and mean relevancy score $>2$ were considered for final selection of statements (Thakur et al., 2017). By this process, 44 statements were selected, which were suitably modified and rewritten as per the comments of the experts.

\section{Item analysis}

Item analysis is an important step in Likert's technique for construction of reliable and valid scale. The purpose of item analysis is to select such items which can very well discriminate between two criterions ${ }^{3}$. The 44 items selected through judges rating were administered to a random sample of 30 farmers from nonsample area.

The respondents were asked to indicate their degree of agreement or disagreement with each statement on the five-point continuum strongly agree, agree, undecided, disagree and strongly disagree. The scoring pattern adopted was 5, 4, 3, 2, 1 for positive statement and for negative statement, the scoring pattern were reversed.
The total score of a respondent was computed by summating his scores for all the individual items. Based upon the total scores, the respondents were arranged in descending order. The top 25 per cent of the respondents with their total scores were considered as the high group and the bottom 25 per cent as the low group, so as these two groups provide criterion groups in terms of evaluating the individual statements as suggested by Edwards (1957).

Thus out of 30 farmers to whom the items were administered for the item analysis, 8 farmers with lowest, 8 farmers with highest scores were used as criterion groups to evaluate individual items.

The critical ratio, that is the ' $t$ ' value which is a measure of the extent to which a given statement differentiates between the high and low groups of the respondents for each statements was calculated by using the formula suggested by Edward (1957).

$t=\frac{X_{H}-X_{L}}{\sqrt{\frac{s_{H}^{2}}{n_{H}}}+\frac{s_{L}^{2}}{n_{L}}}$

Where,

$\mathrm{X}_{\mathrm{H}}=$ the mean score on a given statement for the high group

$\mathrm{X}_{\mathrm{L}}=$ the mean score on the same statement for the low group

$\mathrm{S}_{\mathrm{H}}^{2}=$ the variance of the distribution of responses of high group to the statement

$S^{2}{ }_{L}=$ the variance of the distribution of responses of low group to the statement

$\mathrm{n}_{\mathrm{H}}=$ number of subjects in the high group

$\mathrm{n}_{\mathrm{L}}=$ number of subjects in the low group 


\section{Final selection of statements}

After computing the " $\mathrm{t}$ " values for all the selected items, 30 statements with the highest " $t$ " values equal to or greater than 2.75 were finally selected and included in the final scale.

The thumb rule of rejecting items with " $\mathrm{t}$ " value less than 2.75 was followed (Edwards, 1957).

\section{Standardization of scale}

The scale developed was further standardized by testing its reliability and validity of scale.

\section{Reliability}

In the present study, split-half method was used for measuring reliability of scale. The final set of 30 statements were split into two equal halves on the basis of odd and even number statements and administered to a group of 30 farmers who were not included in the actual sample.

The Karl Pearson product-moment correlation coefficient was calculated was calculated and was found to be 0.77 between the two sets of scores.

The ' $r$ ' value was significant at one percent level of significance indicating that the scale is highly suitable for measuring the perspective of farmers' towards agriculture.

\section{Validity of the scale}

As the content of the attitude scale was derived with utmost care by screening relevant literature and expert opinion, it was assumed that present scale satisfies the content validity. As all the scale construction steps were followed with utmost carefulness, it was assumed that the attitude scale measures what was intended to measure.

\section{Results and Discussion}

The final scale consisted of 30 statements. The responses had to be recorded on a five point continuum representing strongly agree, agree, undecided, disagree, and strongly disagree with scores of 5, 4, 3, 2 and 1 for positive statements and vice-versa for negative statements. The attitude score of each respondent can be calculated by summation of the scores obtained by him on all the items.

The attitude score on this scale ranges from 30 to 150 . The higher score indicates that respondent's perspective towards agriculture as a livelihood is positive and vice-versa.

The rural areas in India are experiencing a rapid change in terms of employment opportunities available in the non-farm sector. The share of population which used to be solely dependent on agriculture for livelihood is gradually diversifying their income earning sources and some have even left he agriculture scenario altogether.

It is high time we try to know the perspectives of practicing farmers towards agriculture which has been their way of life which can be helpful in devising future strategies for rural upliftment in India - whether the policy makers should continue to advocate for a proagriculture strategy for upliftment of rural population or move the large disproportionate population engaged in agriculture to non-farm sectors.

This scale is intended to assess the level of satisfaction of practicing farmers towards agriculture as a livelihood. Further, the scale can also find use in determining perspectives of farmers' towards agriculture in other developing countries like India where agriculture is the mainstay of the rural populations' existence with slight modifications (Table 1-3). 
Table.1 Selection of statements based on judges: Relevancy percentage (RP), Most relevancy score (MRS) and Relevancy weightage (RW) score

\begin{tabular}{|c|c|c|c|c|}
\hline y & Statements & $\mathbf{R P}$ & RW & MRS \\
\hline 1 & Agriculture cannot guarantee food security of my household* & 92.50 & 0.91 & 2.75 \\
\hline 2 & Agriculture ensures economic welfare of my family. & 85.00 & 0.78 & 2.35 \\
\hline 3 & Farmers' are left with very few savings at the end of the season* & 87.50 & 0.88 & 2.63 \\
\hline 4 & Stability in income from agriculture is quite difficult* & 75.00 & 0.71 & 2.13 \\
\hline 5 & Farmers' have a sack of liabilities, no profits* & 87.50 & 0.83 & 2.50 \\
\hline 6 & $\begin{array}{l}\text { Rural population can count on agriculture to solve their problem of } \\
\text { shortages. }\end{array}$ & 72.50 & 0.74 & 2.23 \\
\hline 7 & $\begin{array}{l}\text { Income from agriculture is sufficient to meet the expenditures of a } \\
\text { household }\end{array}$ & 75.00 & 0.73 & 2.18 \\
\hline 8 & $\begin{array}{l}\text { It is not wise to depend solely on agriculture to meet household } \\
\text { requirements* }\end{array}$ & 72.50 & 0.74 & 2.23 \\
\hline 9 & Farmers feed the whole society but cannot feed themselves* & 42.50 & 0.50 & 1.50 \\
\hline 10 & Agriculture has increased my liabilities* & 67.50 & 0.63 & 1.86 \\
\hline 11 & Farming is a stress-free occupation & 75.00 & 0.67 & 2.00 \\
\hline 12 & Agriculture is the answer to all our problems & 55.00 & 0.54 & 1.63 \\
\hline 13 & Life of a farmer is a life of shortages* & 65.00 & 0.60 & 1.80 \\
\hline 14 & Farmers' are neglected in the modern society* & 90.00 & 0.76 & 2.28 \\
\hline 15 & Farmers' are not taken into confidence by formal financers* & 80.00 & 0.75 & 2.25 \\
\hline 16 & The voice of a farmer has importance in the society & 72.50 & 0.75 & 2.25 \\
\hline 17 & Farmers' are categorised along with the peasants* & 90.00 & 0.73 & 2.20 \\
\hline 18 & $\begin{array}{l}\text { The last man to be consulted in important matters in the society is a } \\
\text { farmer* }\end{array}$ & 70.00 & 0.70 & 2.10 \\
\hline 19 & Farmers have good presence in the village councils & 92.50 & 0.80 & 2.40 \\
\hline 20 & A farr & 75.00 & 0.73 & 2.18 \\
\hline 21 & Farmer's do not have bargaining power* & 75.00 & 0.76 & 2.28 \\
\hline 22 & Remunerations for a farmer's efforts are an insult to their abilities* & 57.50 & 0.58 & 1.73 \\
\hline 23 & There is a sense of gratitude for farmers in the society & 67.50 & 0.62 & 1.85 \\
\hline 24 & The rich and poor division does not exist in the farming community & 60.00 & 0.56 & 1.68 \\
\hline 25 & The social acceptance of farming is very low* & 67.50 & 0.68 & 2.05 \\
\hline 26 & Farmers are the new untouchables of the society* & 70.00 & 0.66 & 1.98 \\
\hline 27 & It is economical to lease out farmlands to tenant farme & 82.50 & 0.76 & 2.28 \\
\hline 28 & Family labour contributes the majority of labour in agriculture & 95.00 & 0.91 & 2.73 \\
\hline 29 & $\begin{array}{l}\text { Very few money is invested back to the farm after meeting all } \\
\text { expenditures* }\end{array}$ & 72.50 & 0.78 & 2.33 \\
\hline 30 & Small mistakes in farming decisions can cost dearly* & 75.00 & 0.78 & 2.33 \\
\hline 31 & $\begin{array}{l}\text { Scattered landholdings make it hard for farmers to manage farms } \\
\text { efficiently* }\end{array}$ & 82.50 & 0.78 & 2.35 \\
\hline 32 & Labour for agriculture is easily available. & 92.50 & 0.88 & 2.65 \\
\hline 33 & $\begin{array}{l}\text { Maximization of income with respect to investment is a delusion in } \\
\text { agriculture* }\end{array}$ & 85.00 & 0.78 & 2.33 \\
\hline
\end{tabular}



and money*

37 Agriculture is the connotation of inefficiency*

Present generation cannot manage their farm as well as their

$42.50 \quad 0.52$
forefather's*

39 Labourers do not want to work on agriculture farms*

\begin{tabular}{l|l|l}
37.50 & 0.49 & 1.48
\end{tabular}

Agriculture as a way of life gives me peace and happiness

$92.50 \quad 0.83$

Family farm is a lifestyle worth preserving

75.00

Agriculture gives me opportunity to stay close to my land

85.00

0.79

2.38

I am proud of being introduced as a farmer

\begin{tabular}{l|l|l|l}
75.00 & 0.78 & 2.0 \\
\hline
\end{tabular}

2.50

One feels homely when staying close to the farming community

$90.00 \quad 0.84$

2.33

City life is more satisfying than rural life*

$82.50 \quad 0.72$

2.53

Agriculture is my contribution to society

72.50

2.15

It is very important to me that the farm stay in the family for at least the

95.00

0.74

2.23 next generation

The enjoyment we receive from the farming way of life is incomparable

True happiness lies in growing our own food

$90.00 \quad 0.80$

2.48

I am grateful to the land for providing me with food

$75.00 \quad 0.73$

2.40

$62.50 \quad 0.59$

2.20

Being engaged in agriculture gives me available time to spend in leisure activities

Cash benefits outside agriculture are no compensation for loss of my

\begin{tabular}{l|l|l}
75.00 & 0.67
\end{tabular}

1.78 lifestyle

53 Additional income from off-farm employment has become critically necessary for agricultural household*

Scattered landholdings do not allow farmers to go for commercial

$70.00 \quad 0.64$

2.00 farming*

55 Migration from village to city is an indicator of success in the farming community

56 Today, Farmers' keep looking for alternate livelihood options*

Farming as a career is full of opportunities

87

\begin{tabular}{lll}
87.50 & 0.74 \\
\hline
\end{tabular}

1.93

Proceeds from agriculture have played an important role in increasing

$95.00 \quad 0.87$
my net worth

59 Youths should not practice farming*

\begin{tabular}{lll|l}
95.00 & 0.89 & 2.68
\end{tabular}

The scope of growth in agriculture is very limited*

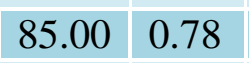

2.35

\begin{tabular}{l|l|l|l}
87.50 & 0.79 & 2.38
\end{tabular}

61 Farming as career is very much challenging*

\begin{tabular}{|l|l|l|l}
65.00 & 0.63 \\
\hline
\end{tabular}

1.90

The younger generation has a negative feel about agriculture as a

$75.00 \quad 0.68$

2.03 profession*

63 The new generation is reluctant to enter farming*

\begin{tabular}{l|l|l|l}
42.50 & 0.51 & 1.53
\end{tabular}

Agriculture is our wisest pursuit

\begin{tabular}{|l|l|l|}
37.50 & 0.48 & 1.43
\end{tabular}

65

Growth in non-farm employment causes people to move away from farming

\begin{tabular}{|l|l|l}
47.50 & 0.53
\end{tabular}

1.60

\footnotetext{
*Negative statements
} 
Table.2 Statements of item analysis by farmers of non-sample area

\begin{tabular}{|c|c|c|}
\hline SI. & Statements & 't' value \\
\hline 1 & Agriculture cannot guarantee food security of my household* & 3.12 \\
\hline 2 & Agriculture ensures economic welfare of my family. & 3.67 \\
\hline 3 & Farmers' are left with very few savings at the end of the season* & 3.65 \\
\hline 4 & Stability in income from agriculture is quite difficult* & 2.78 \\
\hline 5 & Farmers' have a sack of liabilities, no profits* & 2.89 \\
\hline 6 & Rural population can count on agriculture to solve their problem of shortages & 3.01 \\
\hline 7 & Income from agriculture is sufficient to meet the expenditures of a household & 1.56 \\
\hline 8 & It is not wise to depend solely on agriculture to meet household requirements* & 1.66 \\
\hline 9 & Farmers' are neglected in the modern society* & 3.23 \\
\hline 10 & Farmers' are not taken into confidence by formal financers* & 2.93 \\
\hline 11 & The voice of a farmer has importance in the society & 4.15 \\
\hline 12 & Farmers' are categorised along with the peasants* & 2.89 \\
\hline 13 & The last man to be consulted in important matters in the society is a farmer* & 3.67 \\
\hline 14 & Farmers have good presence in the village councils & 2.98 \\
\hline 15 & A farmer can introduce himself proudly in society at all times & 1.45 \\
\hline 16 & Farmer's do not have bargaining power* & 1.67 \\
\hline 17 & It is economical to lease out farmlands to tenant farmers & 3.68 \\
\hline 18 & Family labour contributes the majority of labour in agriculture & 3.62 \\
\hline 19 & Very few money is invested back to the farm after meeting all expenditures* & 3.57 \\
\hline 20 & Small mistakes in farming decisions can cost dearly* & 2.91 \\
\hline 21 & Scattered landholdings make it hard for farmers to manage farms efficiently* & 2.87 \\
\hline 22 & Labour for agriculture is easily available. & 3.65 \\
\hline 23 & Maximization of income with respect to investment is a delusion in agriculture* & 1.97 \\
\hline 24 & Thoughts of selling off my farmland have often crossed my mind* & 2.36 \\
\hline 25 & I prefer to invest my profit in off-farm activities & 2.67 \\
\hline 26 & Maintenance of farming tools and equipment take away a lot of time and money* & 1.55 \\
\hline 27 & Agriculture as a way of life gives me peace and happiness & 4.32 \\
\hline 28 & Family farm is a lifestyle worth preserving & 3.78 \\
\hline 29 & Agriculture gives me opportunity to stay close to my land & 3.89 \\
\hline 30 & I am proud of being introduced as a farmer & 4.13 \\
\hline 31 & One feels homely when staying close to the farming community & 3.97 \\
\hline 32 & City life is more satisfying than rural life* & 3.76 \\
\hline 33 & Agriculture is my contribution to society & 1.92 \\
\hline 34 & $\begin{array}{l}\text { It is very important to me that the farm stay in the family for at least the next } \\
\text { generation }\end{array}$ & 1.87 \\
\hline 35 & The enjoyment we receive from the farming way of life is incomparable & 2.23 \\
\hline 36 & True happiness lies in growing our own food & 1.93 \\
\hline 37 & $\begin{array}{l}\text { Additional income from off-farm employment has become critically necessary for } \\
\text { agricultural household* }\end{array}$ & 3.56 \\
\hline 38 & Scattered landholdings do not allow farmers to go for commercial farming* & 4.32 \\
\hline 39 & Migration from village to city is an indicator of success in the farming community & 3.73 \\
\hline 40 & Today, Farmers' keep looking for alternate livelihood options* & 3.33 \\
\hline 41 & Farming as a career is full of opportunities & 3.93 \\
\hline 42 & Proceeds from agriculture have played an important role in increasing my net worth & 4.06 \\
\hline 43 & Youths should not practice farming* & 2.66 \\
\hline 44 & The scope of growth in agriculture is very limited* & 2.12 \\
\hline
\end{tabular}

*Negative statements 
Table.3 Statements selected for inclusion in the final scale

\section{Sl. Statements}

\begin{tabular}{l|l|l|l|l|l|} 
SA & A & UD & DA & SDA
\end{tabular}

1 Agriculture cannot guarantee food security of my household*

2 Agriculture ensures economic welfare of my family.

3 Farmers' are left with very few savings at the end of the season*

4 Stability in income from agriculture is quite difficult*

5 Farmers' have a sack of liabilities, no profits*

6 Rural population can count on agriculture to solve their problem of shortages

7 Farmers' are neglected in the modern society*

8 Farmers' are not taken into confidence by formal financers*

9 The voice of a farmer has importance in the society

10 Farmers' are categorised along with the peasants*

11 The last man to be consulted in important matters in the society is a farmer*

12 Farmers have good presence in the village councils

13 It is economical to lease out farmlands to tenant farmers

14 Family labour contributes the majority of labour in agriculture

15 Very few money is invested back to the farm after meeting all expenditures*

16 Small mistakes in farming decisions can cost dearly*

17 Scattered landholdings make it hard for farmers to manage farms efficiently*

18 Labour for agriculture is easily available.

19 Agriculture as a way of life gives me peace and happiness

20 Family farm is a lifestyle worth preserving

21 Agriculture gives me opportunity to stay close to my land

22 I am proud of being introduced as a farmer

23 One feels homely when staying close to the farming community

24 City life is more satisfying than rural life*

25 Additional income from off-farm employment has become critically necessary for agricultural household*

26 Scattered landholdings do not allow farmers to go for commercial farming*

27 Migration from village to city is an indicator of success in the farming community

28 Today, Farmers' keep looking for alternate livelihood options*

29 Farming as a career is full of opportunities

30 Proceeds from agriculture have played an important role in increasing my net worth

*Negative statements

SA: Strongly agree; A: Agree; UD: Undecided; DA: Disagree; SDA: Strongly disagree 


\section{Acknowledgements}

The work was carried out under the guidance of Dr. Rajendra Kumar Talukdar, now retired Professor and ex-chairman of my advisory committee, Department of Extension Education, College of Agriculture, Assam Agricultural University, Jorhat, Assam, with whom I initially interacted and conceptualised the research topic and presented my synopsis.

\section{References}

Edwards, A.L. (1957). Techniques of attitude scale construction. Vakils, Feffer and Simons Private Ltd. 9 Sport Road, Ballard Estate, Bombay (Mumbai) 1.

Jones, M. (2013). The Zimbardo Time Perspective Inventory: Exploring the
Relationships between Time Perspective and Measures of Well-being (unpublished master's thesis, California State University, Chico). p. 6.

Lewin, K. (1951). Field theory in the social sciences: Selected theoretical papers. New York, NY: Harper.

Likert, R. (1932). The method of summated ratings. In: Techniques of attitude scale construction (Cited by AL Edward 1969). Vakils, Feffer and Simons Pvt Ltd, Bombay, India.

Thakur, D., Chander, M. and Sinha, S.K. (2017). A Scale to Measure Attitude of Farmers towards Social Media Use in Agricultural Extension. Indian Res. J. Ext. Edu.:17 (3): 10-15.

\section{How to cite this article:}

Bhargab Baruah and Hemanga Kr. Kalita. 2018. A Scale to Measure the Perspective of Farmers' towards Agriculture. Int.J.Curr.Microbiol.App.Sci. 7(09): 867-875. doi: https://doi.org/10.20546/ijcmas.2018.709.104 